\title{
堆積地盤における上下地震動の特性と Qp 構造 CHARACTERISTICS OF VERTICAL SEISMIC MOTIONS
AND Qp-VALUES IN SEDIMENTARY LAYERS
}

\author{
藤 堂 正 喜*1, 羽鳥敏明*2, 千.葉 脩*3, 高橋克也*4 \\ 武村雅之*5, 田中英朗*6 \\ Masanobu TOHDO, Toshiaki HATORI, Osamu CHIBA, Katsuya TAKAHASHI, \\ Masayuki TAKEMURA and Hideo TANAKA
}

\begin{abstract}
Using seismic records observed in 4 borehole arrays, characteristics of vertical seismic motions in sedimentary layers are investigated. The results are as follows.

1) $P$-waves having intensive effect to vertical component are propagating within sedimentary layers even after the $S$-wave onset time (S-wave part).

2) Frequency dependent $Q$-values for $P$-waves ( $Q p$ ) in Tertiary sediment layers obtained from the optimal analyses to spectral ratios have the tendency to be identical with $Q$-values for S-waves ( $Q s$ ) with the same wavelength.

3) Observed vertical motions in upper ground can be simulated by the multiple reflection theory of $P$-waves based on the optimized velocities and $Q$-values.
\end{abstract}

Keywords : sedimentary layers, vertical seismic motions, wave propagation, $P$ - waves, Qp-values

堆積地盤、上下地震動、波動伝播、P波、Qp 值

1.はじめに

地震動の強さを表わす最大值や応答スペクトルの上 下地震動に関する研究は、水平地震動の研究に比べて 多くはない。構造物の耐震設計の観点からその理由を 見ると、重力加速度による鉛直荷重に抗して設計され た部材は鉛直方向に十分な強さを有しており、上下地 震動による鉛直荷重は重力によるものより小さいと考 えられていることにある。ところで、鉛直振動そのも のの影響が大きいと考えられる大スパン構造や原子力 発電所施設等にある機器・配管系、地震応答に影響か 大きい低次振動成分の固有周期が長いことにより相対 的に小さくなる水平荷重に比べて低次の固有周期が短 く短周期成分の寄与が大きい上下震動を受ける高層建 物では、上下地震動による荷重を考慮して構造物の安 全性を検討する必要があろう。

*1 戸田建設技術研究所

プロジェクトサブマネージャー・工博

*2 户田建設技術研究所 課長

*3 戸田建設技術研究所 室長・工修

*4 鹿島技術研究所 主管研究員

*5 鹿島小堀研究室。主任研究員・理博

*6 東京電力原子力建設部 副長・工修
上記の上下地震動の強さを表わす尺度に関する地震 観測記録に基づく研究は、水平地震動に関する研究蓄 積の豊富さを考慮して、絶対的な尺度は水平地震動に 求め、それに対する相対的な比の形式で表わされるこ とが比較的多い。すなわち、ある地震による当該敷地 における上下地震動強さを、水平地震動の距離減衰式 から推定される強さに上記の比を乗じて求める考え方 である1。主に地表での観測地震動による応答スペク トルの水平地震動に対する上下地震動の平均的な比に 関する既往研究をみると、経験的には、 $0.2 \sim 1$ 秒程度 の周期領域では0.4〜0.7程度の比であり、0.1秒付近 では両成分のスペクトル值が同程度にもなるとの結果 がまとめられている2)。

ところで、観測地震動は、震源、パスおよび堆積地 盤による増幅特性の3つの主要な要因の影響を受けて

Technical Research Institute, Toda Corporation, Dr. Eng.

Technical Research Institute, Toda Corporation Technical Research Institute, Toda Corporation, M. Eng. Kazima Technical Research Institute, Kazima Corporation Kobori Research Complex, Kazima Corporation, Dr. Sci. Nuclear Power Construction Department, Tokyo Electric Power Company, M. Eng. 
いる。従って、上記の既往研究にみられる水平地震動 に対して上下地震動のスペクトル比が周期領域で一定 の比ではなく周期特性を有している傾向は、両成分が 受ける上記 3 要因のいずれかの周期特性が異なってい ることを示唆している。このことから判断すると、単 に上記のような平均的なスペクトル比を水平地震動の スペクトルに乗じて得られる上下地震動のスペクトル 特性は、上記の 3 要因を適切に反映しているとは考え られない。

ここで、震源から伝播してある敷地付近の地震基盤 に達する直達 $\mathrm{P}$ 波または直達 $\mathrm{S}$ 波では水平成分、上下 成分に関わらず理論的に震源とパスの影響はほぼ同一 であるといえる。たとえば、物理的意味に基づく応答 スペクトルの距離減衰式 ${ }^{3)}$ を用いた水平地震動と上下 地震動各々の観測記録に基づく回帰分析結果は上記の 結論を支持している4)。従って、前述のようにスペク トル比が周期特性を有する原因は、水平地震動と上下 地震動が受ける地盤增幅特性の違いによる所が大きい と考えられる。

本研究は、上下地震動に及ぼす堆積地盤の影響とし て、地盤内における波動伝播特性、およびそれへの影 響が大きい地盤内の $\mathrm{P}$ 波の $\mathrm{Q}$ 值 $(\mathrm{Qp})$ について鉛直 アレー観測記録を用いて検討したものである。これら は、本論文で用いるのと同じ観測地点における水平地 震動記録によるS 波のQ $\mathrm{Q}$ 值 (Qs) に関する検討結果 ${ }^{5)}$ と対比して議論される。

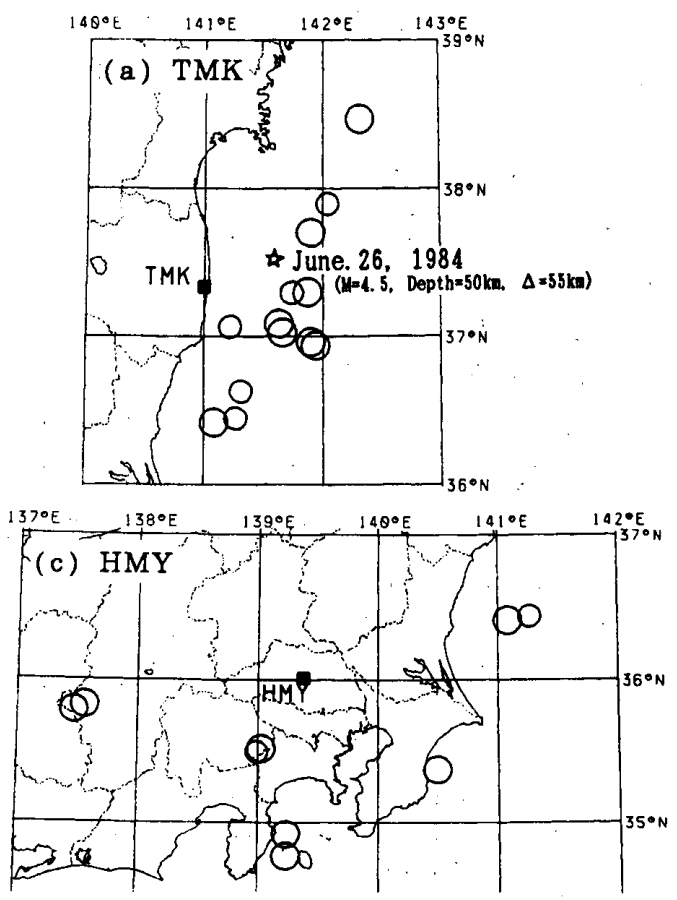

\section{2. 解析に用いたテータ}

用いたデー夕は、Fig.1に示す 4 観測地点における 鉛直アレー観測によるものである。各観測地点にて実 施した P S 検首による地盤の速度構造 ${ }^{8)}$ とボアホール 内に加速度計を設置した測点位置をFig.2に示す。

各観測地点における最梁測点は、TMKとIWKでは $\mathrm{S}$ 波 速度 Vsが約 $3 \mathrm{~km} / \mathrm{s} 、 \mathrm{P}$ 波速度 V pが約 $5.5 \mathrm{~km} / \mathrm{s}$ の花崗岩 の地層に位置し、HMYとSZJでは新第三紀中新世の地層 に位置している。ここで、各観測地点で $3 つ$ 黒丸で 示した測点のうちで中間に位置する測点は、地表近傍 の第四紀層や風化層と古第三紀または新第三紀中新世 の地層との境界付近に位置し、以後中間点と呼ぶ。

用いた観測記録は、1980年から1990年の間に得られ た、マグニチュードが5.5以上（最大 $7.0 ） 、$ 震源樑さ が $60 \mathrm{~km}$ 以浅で震央距離が $200 \mathrm{~km}$ 以下となる 33 地震に よるものである。それらの震央位置をFig.1に示す。

\section{3. 深い鉛直アレー観測記録の解析}

鉛直アレーが最も深いTMKの地盤は、Fig.2(a)から わかるようにV sが約 $3 \mathrm{~km} / \mathrm{s}$ の基盤層のすぐ上の深さが $920 \mathrm{~m} \sim 830$ mの位置で速度構造の変化が大きい。TMKの 観測記録を例に、堆積地盤内における上下地震動の波 動伝播の特徵を以下に示す。

用いる記録は、直達 $\mathrm{P}$ 波および直達 $\mathrm{S}$ 波がパルス的 でフェースが識別しやすい1984年6月26日の地震（マ

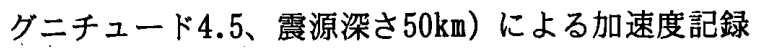
で、それを積分して求めた速度波形である。その地震 の震央をFig.1(a)に併記した。この記録のP 波初動付
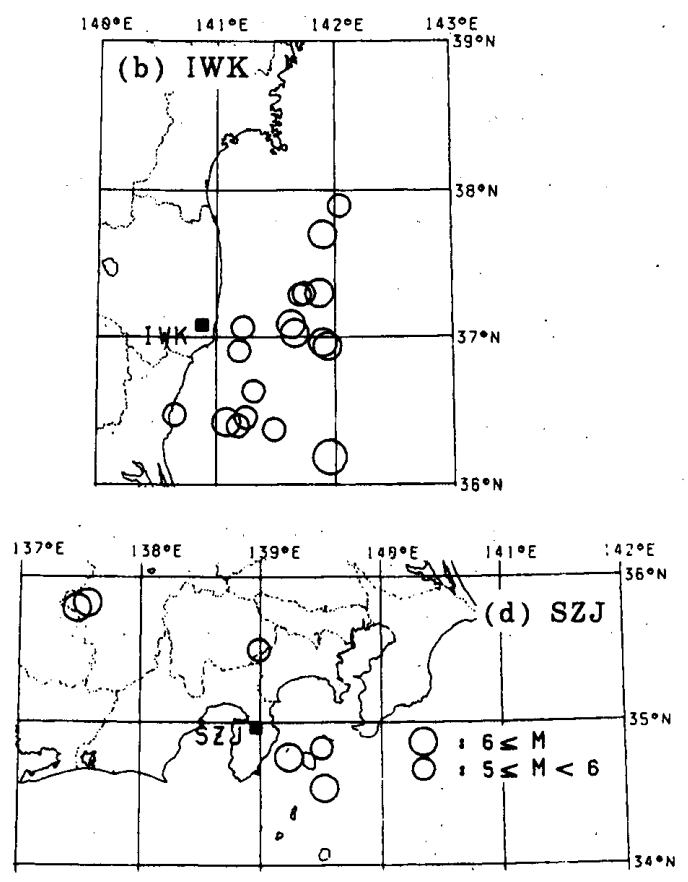

Fig.1 Location of observation stations and epicenters of earthquakes used in the analyses. 


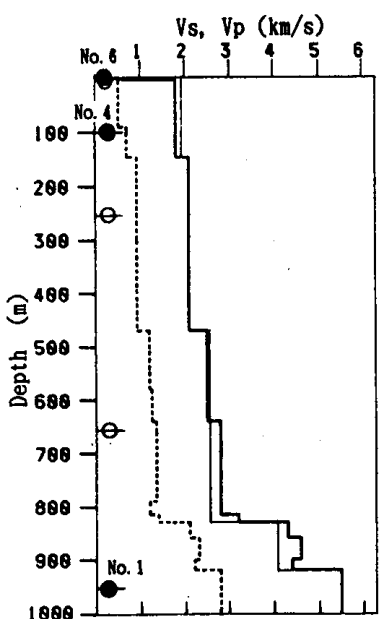

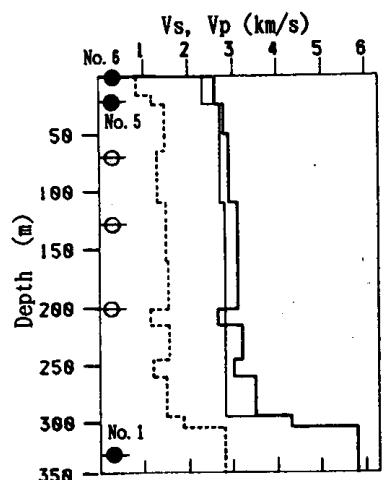

(b) IWK

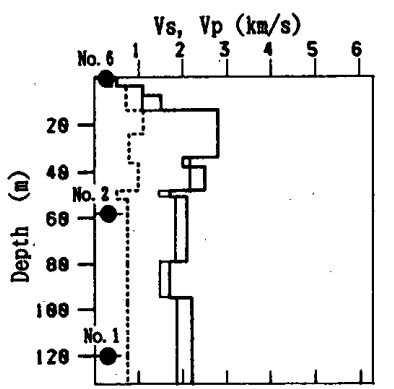

(c) HMY

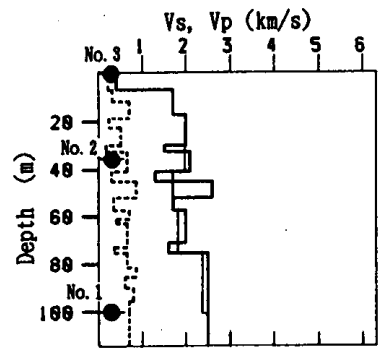

(d) SZJ

. Observation point

Fig.2 Velocity structures for $\mathrm{P}$ - and S-waves of the ground obtained from the PS-logging, which are shown by thick solid and dotted lines, respectively. The thin solid lines indicate the optimized results for $P$-wave velocity. The records at the points shown in solid circles are used in the analyses.

近の上下動波形をFig.3(-a)に示す。また S 波初動付近 の上下動波形と水平動 2 成分から合成したラジアル成 分の波形をFig.3(b)に示す。横軸の時間は観測記録の 開始時間からのものである。Fig.3(a)と(b)のように、 震源から伝播してきた直達 $\mathrm{P}$ 波と直達 $\mathrm{S}$ 波ならびにそ れに続く部分をここでは $\mathrm{P}$ 波部、 $\mathrm{S}$ 波部と称する。
Fig.3(a)の実線は、GL-950mの最深点の直達 $\mathrm{P}$ 波の 到達時刻を基準に、Fig.2(a)のP波速度構造に従って 上昇、下降する主な波の理論走時を示している。実線 にはそれぞれの深さでバルスが対応し、基盤から入射 した P 波が地表やGL-470m、基盤層上面なと顕著な地 層境界で多重反射している様子がよく分かる。

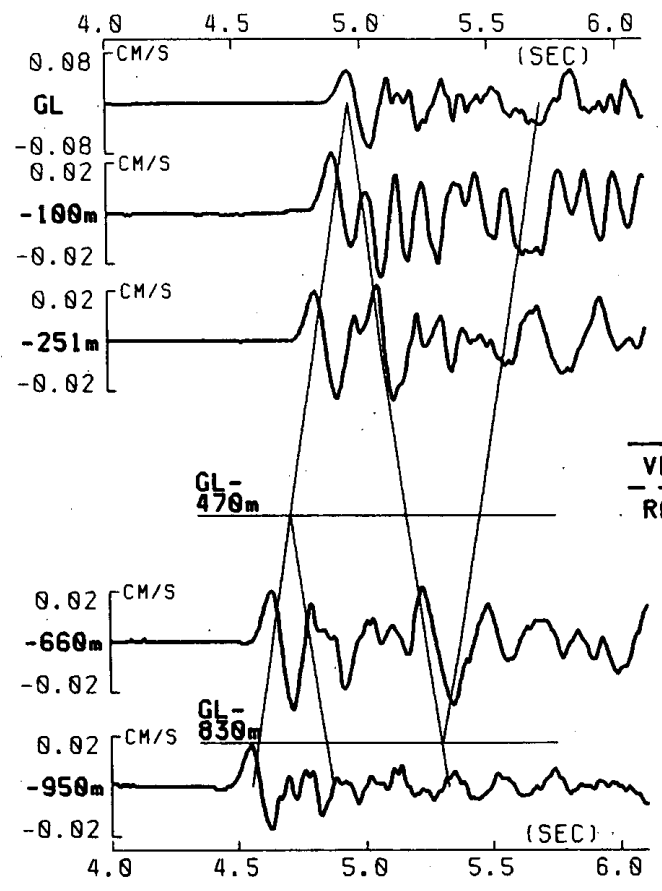

(a) P-wave Part

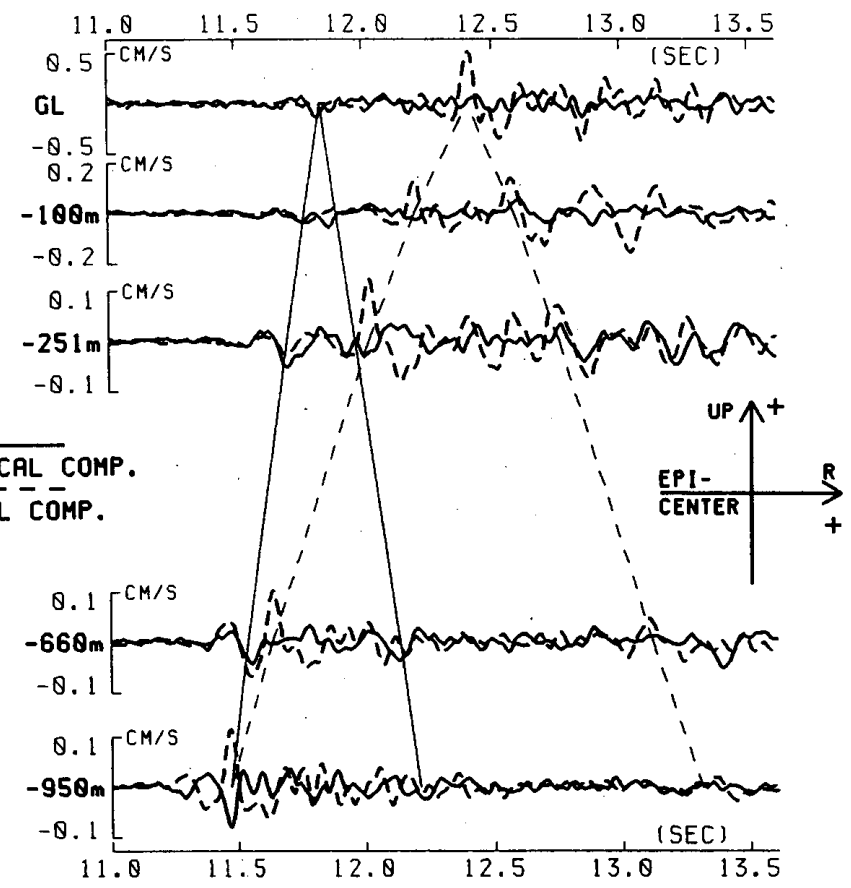

(b) S-wave Part

Fig.3 Wave forms of vertical array records at TMK, which are pasted up following the travel time calculated from the $P$-wave velocities shown in Fig.2(a). The left (a) and right (b) figures show the initial parts on the records of the $P$-wave part and the $S$-wave part, respectively. 

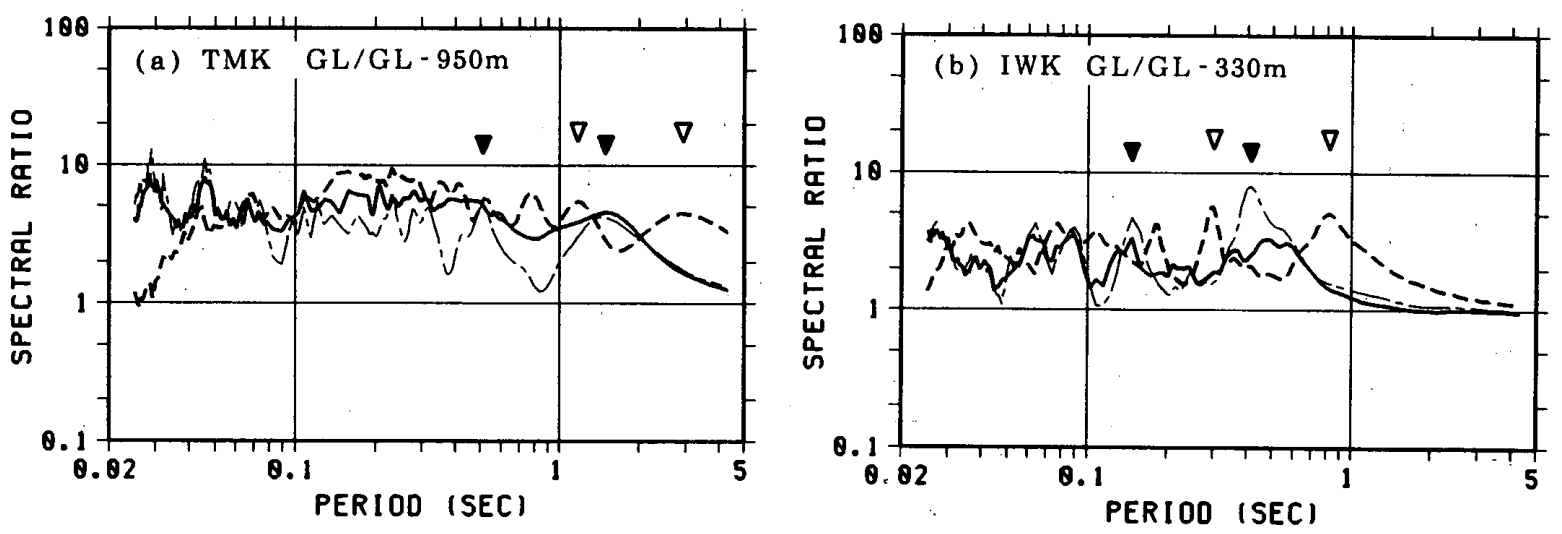

Fig.4 Spectral ratios of records between ground surface and the deepest observation point at TMK (a) and IWK (b). The chained and solid lines are obtained due to vertical components in $P$ - and $S$-wave part, respectively. The dotted line shows ratios for the S-wave part of horizontal components.

Fig.3(b)の950m測点の波形に注目すると、11.5秒付 近にみられるフェーズは S V 波の振動方向を示してい る。これら上下、ラジアル成分による粒子軌跡から、 その入射角は約 30 度と推定される。このフェースを基 準に $\mathrm{P}$ 波速度および $\mathrm{S}$ 波速度で上昇、下降する波の理 論走時をそれぞれ実線と破線で示す。上下動成分では 主に実線に沿ってフェーズが確認できるのに対し、ラ ジアル成分では破線に対応したフェーズがよく見える。 すなわち上下動では基盤に入射した S V 波がGL-920m 〜830mにかけてのインビーダンスの変化が大きい基盤 層上面で $\mathrm{P}$ 波に変換した波（S P 変換波）か支配的と なり ${ }^{7} 、 一$ 方ラジアル成分では基盤層上面で透過した $\mathrm{S}$ 波が支配的となることを示している。

上記の現象が上下地震動のスペクトル特性に及ぼす 影響をみるために、Fig.1(a)のTMKにおける13地震の 上下動と水平動の観測記録を、 $\mathrm{S}$ 波初動以後の $\mathrm{S}$ 波部 と $\mathrm{P}$ 波初動から $\mathrm{S}$ 波初動前までの $\mathrm{P}$ 波部に分離して、 各記録のフーリエ振幅スペクトルの 950 m測点に対する 地表のスペクトル比を求めた。それら $\mathrm{S}$ 波部と $\mathrm{P}$ 波部 におけるスベクトル比の幾何平均をFig.4(a)に実線と 一点鎖線で示す。図中の破線は水平動の $\mathrm{S}$ 波部におけ るスベクトル比である。これと上下動の S 波部のスヘ クトル比を比較すれば両者は明らかに異なっており、 1 次卓越ビークの周期は水平動が2.92秒であるのに对 し上下動は 1.49 秒である。 2 次のビーク周期も上下動 は水平動に比べて $1 / 2$ 程度の周期に出ており、地表近 傍地盤の影響が大きい0.1秒以下においても上下動は 水平動に比べてより短周期まで大きな比となっている。 このS 波部の上下動スベクトル比を、一点鎖線で示し た $\mathrm{P}$ 波部の上下動スベクトル比と比較すると、1 次ピ ークの周期は一致しており 2 次ビークの周期もほぼ対 応している。このように上下動の $\mathrm{P}$ 波部と $\mathrm{S}$ 波部のス ペクトル比は、絶対值はやや異なるもののピークの位
置など全体的に類似した傾向を示している。

同様に、Fig.1(b)に示すIWKにおける観測記録から、 330m測点に対する地表の平均スベクトル比を求め、そ の結果をFig.4(b)に示す。1 次卓越ピークの周期は、 水平動 $\mathrm{S}$ 波部では0.82秒であるが、上下動 $\mathrm{S}$ 波部では $\mathrm{P}$ 波部の0.42秒に近い0.5秒付近の周期に現れている。 また、それそれれの成分の 2 次ビークの周期はともに 1 次ビーク周期の約 $1 / 3$ あ゙ある

このように、上下動 $\mathrm{S}$ 波部のスペクトル比は、水平 動とは異なり上下動 $\mathrm{P}$ 波部のスペクトル比と良く似て いる。つまり、 $\mathrm{S}$ 波部であっても上下動では基盤層の 上面で $\mathrm{S} V$ 波から $\mathrm{P}$ 波に変換した波が支配的で、 $\mathrm{P}$ 波 部と同様に $\mathrm{P}$ 波が多重反射することにようて特徴付け られると考えられる。

\section{4. 堆積地盤における地震 $\mathrm{P}$ 波の地盤減哀特性}

3 章で述べたように堆積地盤内における上下地震動 については S 波部にあっても地盤内で多重反射する $\mathrm{P}$ 波の影響が大きい。従って、上下動の地盤震動特性に ついて定量的な検討を行うためには、P 波の地盤減衰 特性を適切に設定する必要がある。

鉛直アレ一観測記録を用いて、異なる深さにおける 観測記録のスペクトル比とQ值を変数とした多重反射 理論による計算結果を直接比較して、地盤の $Q$ 值を求 めることはS 波については多く行われている5〉，8，日)。 この際、目標とする镜測スペクトル比として、複数の 地震記録による平均值を用いる方法 ${ }^{5}$ ，8) と個々の地 震による観測スペクトル比に対して地盤定数を求める 方法 ${ }^{9)}$ があり、前者では一組の地盤定数が得られるの に対して後者では個々の結果をサンブルとする統計量 としての地盤定数が得られる。これらの地盤定数を用 いる地盤応答の観点からは、前者では確定的に、後者 では確率・統計的に地盤の応答解析を実施することを 

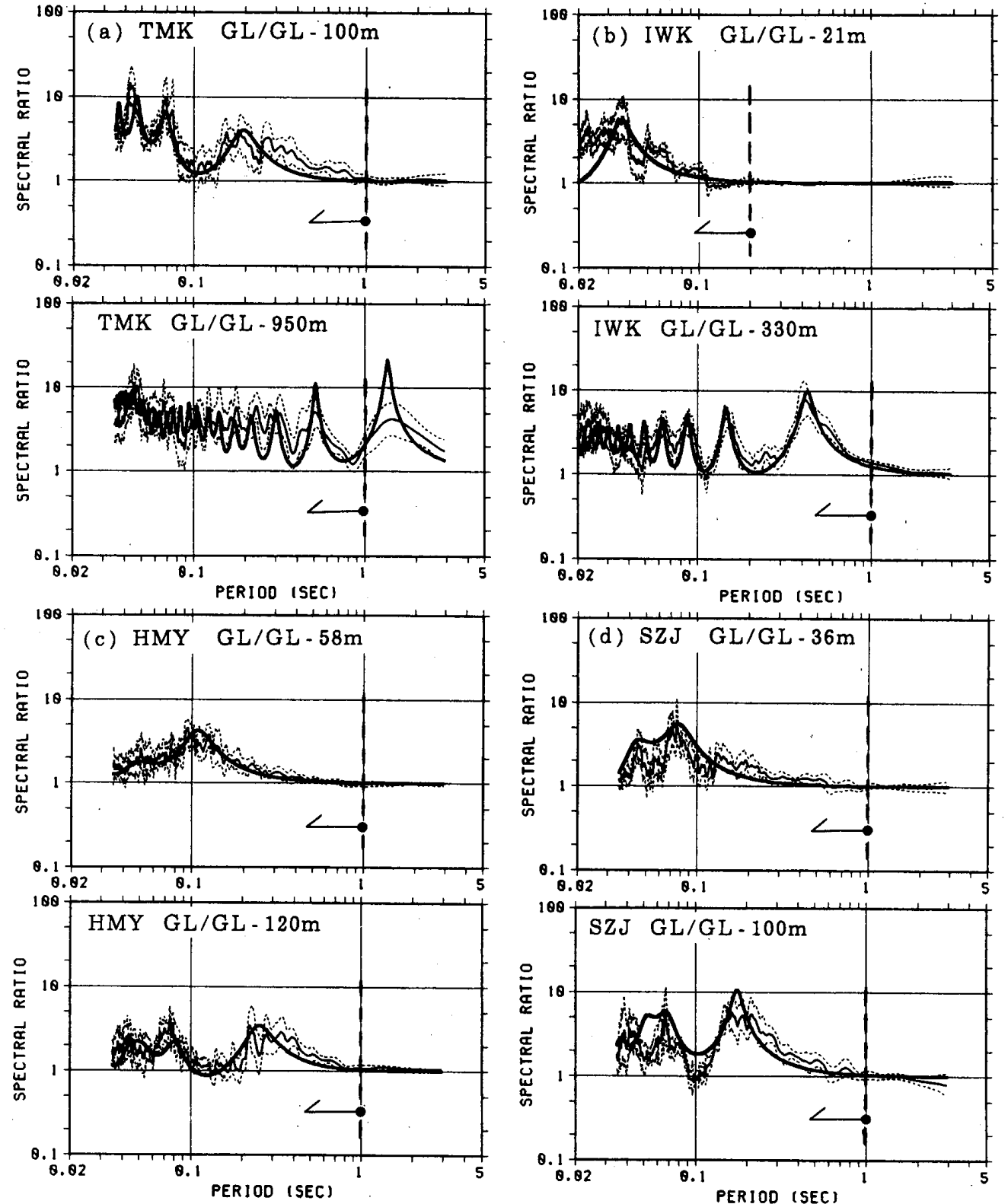

Fig.5 Spectral ratios of seismic motions at ground surface to those at underground. The thin solid and dotted lines indicate the average ratios and ratios considering one standard deviation due to the $P$-wave part of observed vertical components, respectively. The thick solid line, is the ratios calculated by the multiple reflection theory of $P$-waves using the optimized velocities and $Q p$-values.

念頭においていることになる。本研究では、観測スペ クトル比の平均值を対象とする方法を採用して、求ま った地盤定数が地盤応答に及ほす影響をシミュレーシ ヨンによって把握することとする。

Fig.1の地震による各観測地点の記録波形のうち $\mathrm{P}$ 波初動から S 波初動の前までのP 波部の波形を取り出 し、それらのフーリエ振幅スペクトルからスベクトル 比を求めた後、各観測地点の全記録からスペクトル比 の幾何平均を求めた。中間点および最深測点に対する 観測スベクトル比の平均値と標準偏差をFig.5に示す。

Fig.3(a)に示した例のように、P波部の上下動は主
に成層地盤内を多重反射する $\mathrm{P}$ 波によって構成されて いる ${ }^{10)}$ 。従って、基盤への $\mathrm{P}$ 波の鉛直入射を仮定し 多重反射理論を適用して計算されるスペクトル比が観 測された平均スペクトル比にできるだけ適合するよう に、最適化によって地盤定数を定める。具体的には、 (1)式の誤差関数 Jに対して準ニュートン法による非 線形最小二乗法を適用する。

$$
\mathrm{J}=\sum_{\mathrm{k}}\left\{\langle\bar{A}(\mathrm{Tk})>-\mathrm{A}(\mathrm{Tk} ; \mathrm{x})\}^{2}\right.
$$


$\mathrm{Tk}$ はある周期、 $<\overline{\mathrm{A}}(\mathrm{Tk})>$ はF ig.5に示す平均スペクト ル比またはその逆数である。 $\mathrm{A}(\mathrm{Tk} ; \mathrm{X})$ は、未知変数で ある地盤定数 $\mathrm{x}$ を含む地盤構造モデルを用いて計算さ れるスベクトル比またはその逆数である。ここで、最 適化手順や初期值を決めるに当たって実施した予備解 析から、Fig.5(a)に示すTMKの 950m測点に対する観測 スペクトル比を対象とした場合、後述する Q 值の表現 によっては図示した周期範囲の観測値に適合させられ る計算結果を得ることは困難であることがわかった。 そこで本研究では、短周期領域における地盤震動を重 視して、1 秒以下の周期領域におけるスペクトル比を 最適化の対象とする。(1)式の誤差関数に用いるサン プル周期は、 0.05 秒から 1 秒までの周期範囲から、周 期の対数值がほぼ等間隔となる300個の周期を選択し た。ただし、IWKの21測点に対しては、平均スペク.ト ル比のビークが 0.05 秒以下の短い周期にみられること から、0.03秒から0.2秒の周期範囲を対象とした。

最適化は、 $\mathrm{P}$ 波速度、Q值の順に、まず中間点に対 する地表のスペクトル比を用いて地表から中間点まで の未知変数を求めて固定し、次に最深測点に対する地 表のスペクトル比を用いて中間点から最哚測点までの 間の未知変数を求める手順で実施した。ただし、TMK とIWKについては $\mathrm{P}$ 波速度の決定に中間点から最深測 点の間に存在する測点に対するスペクトル比も参考に 用いた。ここで、 $\mathrm{P}$ 波速度の最適化ではスペクトル比 の逆数を対象とし ${ }^{11} 、 \mathrm{Q}$ 值の最適化ではスペクトル 比を用いた。その際、密度は密度検層結果を固定して 用いた。P波速度の最適化における初期值としては、 P S 検層結果に基づくFig.2の地盤構造をやや粗い層 に分割し各層について平均した値を用いた。Q值は、 周波数依存性を仮定し、 $\mathrm{Qp}(\mathrm{f})=\mathrm{Qpo} \cdot \mathrm{f}^{\mathrm{n}}$ (f in $\mathrm{Hz}$ ) と表現し ${ }^{5)}$ 、前述の中間点より上層と下層の地層に大

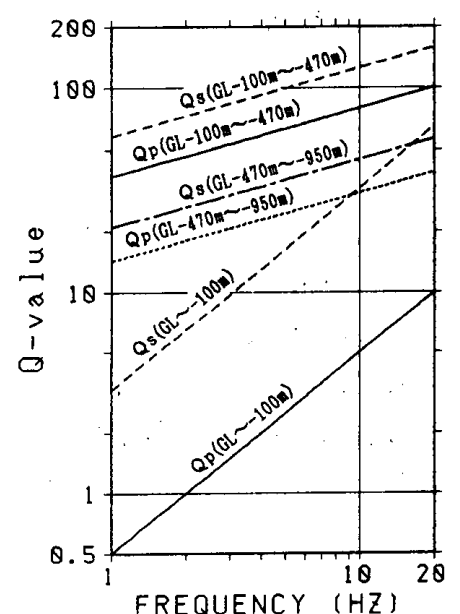

(a) TMK

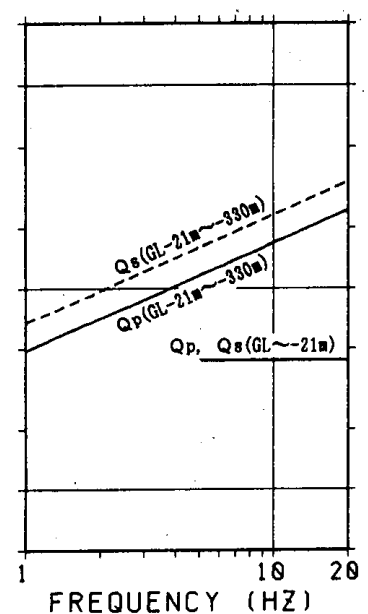

(b) IWK

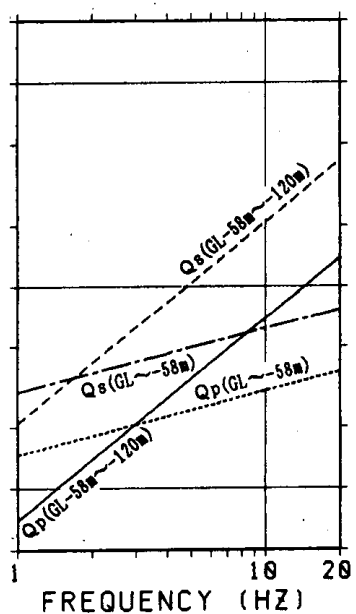

(c) HMY
きく区別して求める。ただしTMKでは下層をさらに新 第三紀と古第三紀の 2 層に区分してQ值を求めた。Q 值の初期值は、同じ地盤の観測記録を用いた $\mathrm{Qs}$ の值 とした ${ }^{5)}$ 。

最適化によって得られた P 波速度をFig.2に、Qpを Fig.6に示す。これらの地盤定数を 1 秒以上にも外挿 して用いて、多重反射理論から得られたスペクトル比 をFig.5に併記した。いずれの場合も最適化の対象と した 1 秒以下の周期範囲において計算值と観測值との 対応は良い。Fig.2から分かるように最適化によるP 波速度は、初期值として与えた P S 検首結果に基つく 速度を殆と変更することなく得られている。成層地盤 の波動の多重反射に関わる一つのファクターとして基 盤首への波の入射角の影響が考えられるが、上記 $\mathrm{P}$ 波 速度の結果は今回用いたデー夕が十分鉛直入射の仮定 を満足するものであることを間接的に示している。

2 章に示した 4 観測地点において、トランスバース 成分記録のスペクトル比に対して S H 波の多重反射理 論を適用した最適化により、すでにQs値が求められ ている ${ }^{5)}$ 。Fig.6に同一観測地点のQ $\mathrm{s}$ 值を併記する。 観測地点毎に $\mathrm{Qp}$ 值とQ $\mathrm{s}$ 值を比較すると、周波数依存 性を示す傾きnはいずれの地点でもほぼ同じである。 またnの範囲は0.3〜1.0となる。これに対し、同一の 周波数においてはいずれの観測地点においてもQp< Qsである。このごととFig.4のように上下動 $\mathrm{P}$ 波部と 水平動 $\mathrm{S}$ 波部のスペクトル比がピークを呈する周期が 波動種別に応じて異なることを考えあわせると、Q值 がスペクトル比のビークに及ぼす影響は対象となる波 動の波長に関係していることが推察される。そこで、 $\mathrm{Q}$ 值の最適化で区分した地層の $\mathrm{P}$ 波と $\mathrm{S}$ 波それそれれの 速度の平均值を使って波長を求め、P波の波長と $\mathrm{Qp}$ 值および S 波の波長とQs值の関係をFig.7に示した。

Fig.6 Frequency dependent $Q$ values $(Q p)$ for $P$-wave of the ground obtained from the optimal analyses in comparison with $Q$ s for $S$-wave (Ref.5). 


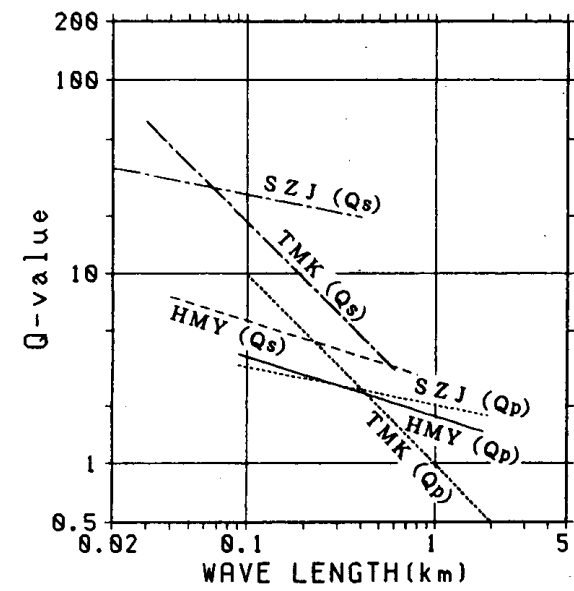

(a) Shallower Strata

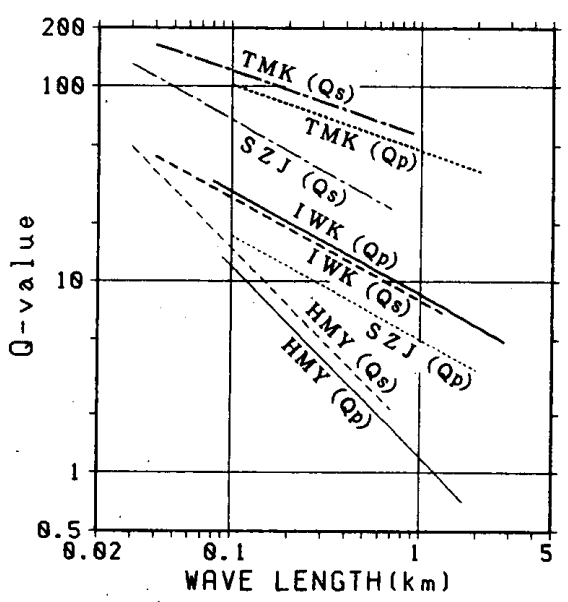

(b) Deeper Strata

Fig.7 Comparison of $Q p$ with $Q s$ in terms of the wavelength of $P$ - and $S$-wave for $Q p$ and $Q s$ respectively. The left (a) and right (b) figures indicate $Q$ values for the shallower and deeper strata, respectively.

ここで(a)は中間点より浅い地層、(b)は深い地層にお ける関係である。これらの結果でまず注目される点は、 Fig.7(b)の新第三紀以前の比較的硬い地層においては SZJを除く 3 地点で同一波長に対し $Q p \fallingdotseq Q s$ 関係か 成り立つことである。この関係は $\mathrm{P}$ 波と $\mathrm{S}$ 波が一波長 進む間のエネルギー損失がほぼ同一であることを意味 しており、基盤層以深の伝播経路において求められた $\mathrm{Qp}$ と $\mathrm{Qs}$ の関係 ${ }^{12)}$ に類似している。つまり $\mathrm{Qp}$ と $\mathrm{Qs}$ に関して以下の関係が成り立つことになる。

$$
Q p(f)=Q s(f) \cdot(V s / V p)^{n}
$$

ただし、上記のようにnは0.3から1.0の範囲にある。

Yoshimoto et al. ${ }^{13)}$ は、 Vpが $1 \mathrm{~km} / \mathrm{s} \sim 4 \mathrm{~km} / \mathrm{s} 、 V s$ が0.5km/s〜2km/sにある風化花崗岩の約 $15 \mathrm{~m}$ のポアホ 一ルにおける最深点と地表間で求めた上下動 $\mathrm{P}$ 波およ び水平動 $\mathrm{S}$ 波のスペクトル比に対し、多重反射理論を 適用している。その際、Qp=Qs/2で上下動 $\mathrm{P}$ 波の スペクトル比がよく説明できると指摘している。(2) 式において上記 VpとVsの関係を考慮すると $\mathrm{n} \doteqdot 1$ の場 合に対応し、本研究の結果とほほ整合する。

一方、Fig.7(a)の第四紀層や風化層に対応した比較 的軟らかい地層おいては(2)式の関係がややくずれ、 同じ波長に対する $Q p$ と $\mathrm{s}$ は平均して $\mathrm{Qp} \doteqdot \mathrm{Qs} / 1.5$ の関係になる。またSZJでは第三紀層においても同一 波長に対しQpはQsに比へててかなり小さく、第四紀層 ではその差はさらに拡大する。SZJは他の 3 地点と異 なり火山性の堆積物によって地層の連続性が悪く、特 にQsを求める際のスペクトル比の最適化の精度が良 〈ない" ${ }^{5)}$ 。従って上記のような他地点との $Q$ 值の関係 の差か、最適化の精度の悪さから生まれたものか地層
そのものの性質から来るものか現状ではよく分からな い。後者の場合には先に指摘した他地点の第四紀層と 第三紀層との違いおよび沖積世にいたる地盤における 特性 ${ }^{14)}$ も含め、地震波の減衰機構との関連で今後検 討されるべき重要課題であると考えられる。

5. 堆積地盤における上下地震動のシミュレーション 4 章で求めた地盤の $\mathrm{P}$ 波速度と $\mathrm{Qp}$ 値による地盤構 造から、地盤内で多重反射する上下地震動をいかほど 再現しえるかを判断するために、各上下動記録のP 波 部についてシミュレーション解析を行った。検討の対 象は地盤定数の最適化範囲に応じた 1 秒以下の周期範 囲であるが、1 秒以上も外挿した $Q$ 值を用いて計算し た。解析法は 4 章で用いた基盤への $\mathrm{P}$ 波鉛直入射によ る多重反射理論であり、各観測地点における最深測点 の記録波形を理論計算による地中内測点位置の応答と 同一においた入力としている。

計算結果の一例として、TMKの地表における計算加 速度波形と記録波形、およびそれらによる減衰定数 $5 \%$ の擬似速度応答スベクトルの比較をFig.8に示す。計 算波形は最大值を含む記録波形の経時変化を良く再現 している。計算波形による応答スペクトルも検討対象 の1秒以下では観測值をほぼ説明し得ている。4 観測 地点の地表について、各記録波形に対する計算波形の 応答スペクトルの比を求め、全記録から平均值と標準 偏差を求めてFig.9に示す。計算波形による応答スぺ クトルは平均的に $25 \%$ 以内の差で観測值に对応し、比 の変動は $20 \%$ 程度以下と小さい。このようにシミュレ ーション解析によって上下動 $\mathrm{P}$ 波部の応答スペクトル が良く推定されていることが分かる。

一方、 3 章で指摘したように $\mathrm{S}$ 波部における上下動 

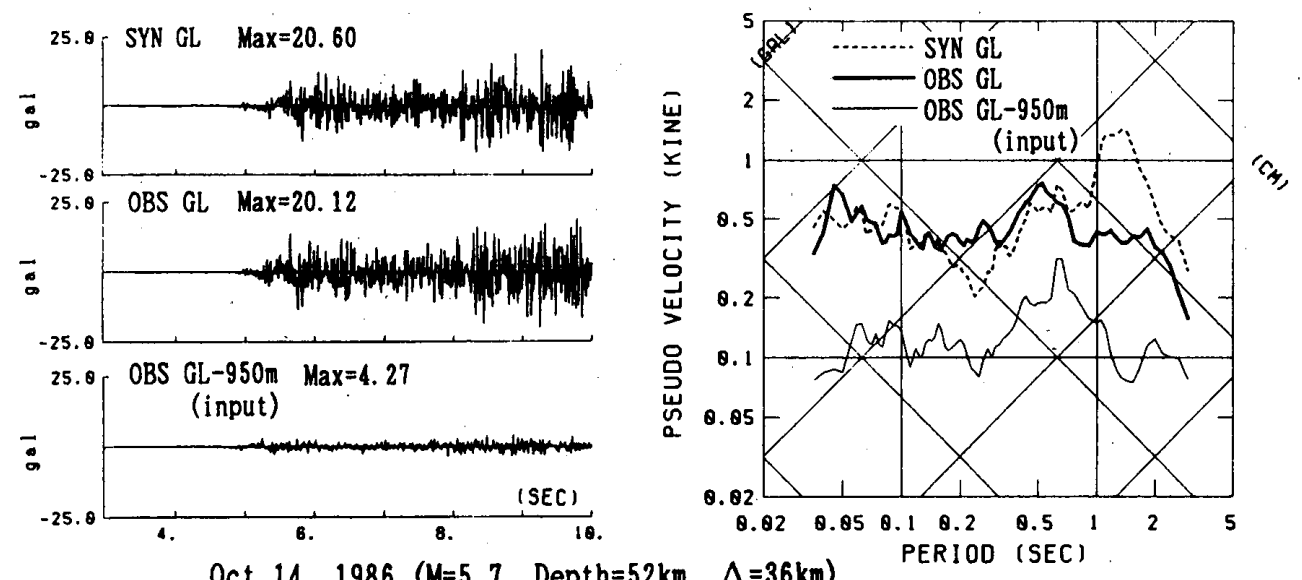

Oct. 14, $1986(M=5.7$, Depth $=52 \mathrm{~km}, \Delta=36 \mathrm{~km})$

Fig.8 An example of the comparison of the vertical accelerogram synthesized by the multiple reflection theory of $P$-waves with the observed record for $P$-wave part at TMK, shown in the left figure. The right figure shows the response spectra with $5 \%$ critical dampings due to their accelerograms.
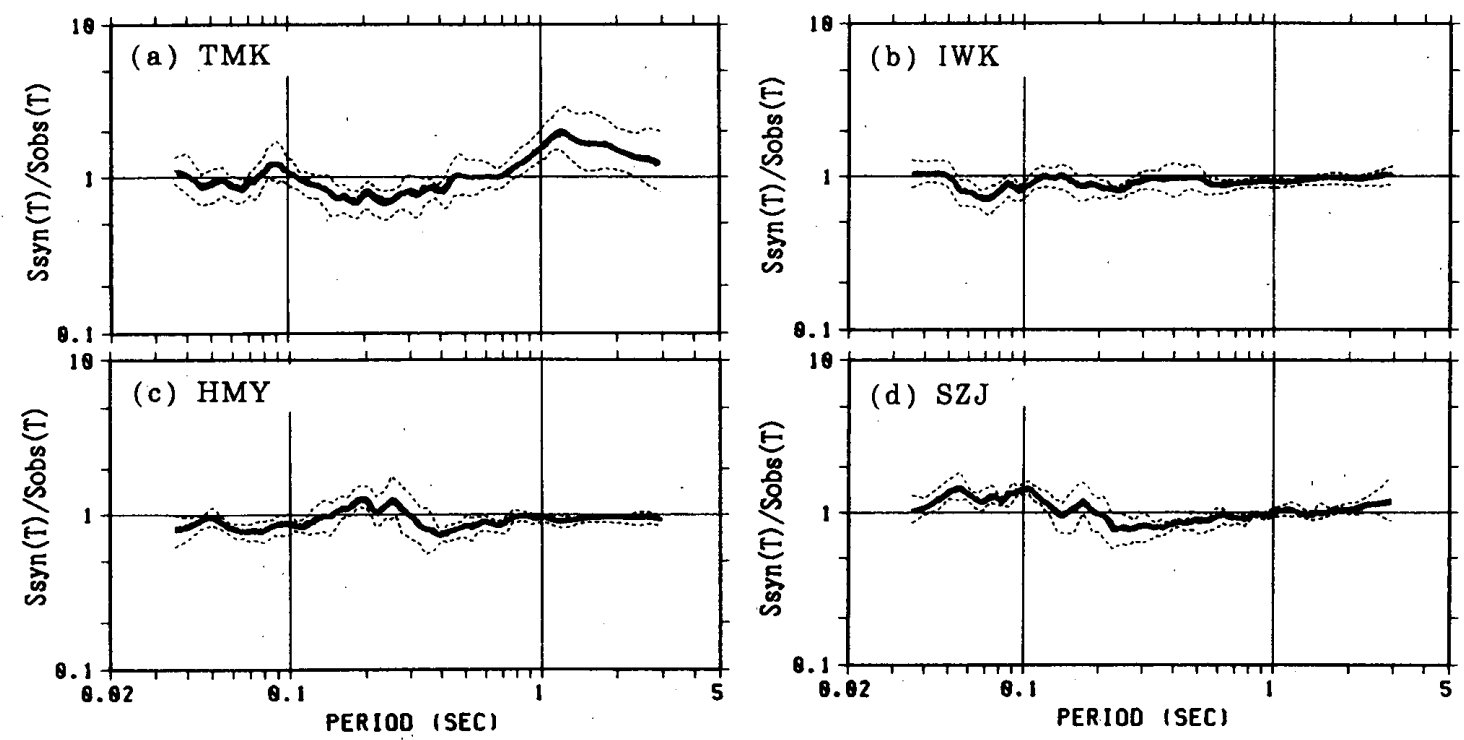

Fig.9 The ratios of response spectra of synthesized vertical accelerograms at the ground surface to those of observed records for $P$ - wave part. The solid and dotted lines show the average ratio and the deviation, respectively.

は、基盤層へ入射した S V 波によって生じていると考 えられ、表層地盤内においては変換 $\mathrm{P}$ 波の多重反射に よる影響を強く受けている。このことは、S 波部につ いても、地表に近い表層地盤においてはP 波の多重反 射を仮定して上下動の波動伝播特性を把握できる可能 性を示唆している。その点の確認も含め、各観測地点 における中間点に $\mathrm{P}$ 波が鉛直入射すると仮定して、中 間点より浅い表層地盤における上下動の $\mathrm{S}$ 波部のシミ ユレーション解析を行った。計算に際しては、中間点 における上下動記録波形を理論計算による地中内応答 と同一においた入力として地表の観測記録を推定した。

計算結果の一例として、Fig.8と同じ記録の $\mathrm{S}$ 波部 について、中間点である100m測点の記録波形を入力と して求めた地表の加速度波形と記録波形、およびそれ
らによる応答スベクトルをFig.10に示す。実線が観測 值、破線が計算值である。計算波形の経時特性は記録 波形によく対応しており、応答スペクトルについても Fig.8の例と同程度によい対応を示す。比較のために 同じ記録について S V 波の斜め入射によるシミュレー ション解析も行った。この場合には、GL-950mにいた る地盤構造を対象として 950 留測点が位置する基盤層に $\mathrm{S} V$ 波が斜め入射すると仮定し、理論計算の中間点に おける応答がその測点の上下動記録と同一となるよう に入力を設定した。基盤に入射する S V 波の角度は、 950 m測点記録波形のS 波立ち上がり付近の粒子軌跡か ら23度とした。これによる計算から求めた地表におけ る波形とその応答スペクトルをFig.10に併記した。先 の結果と比較すれば、両者は観測記録を同程度に再現 

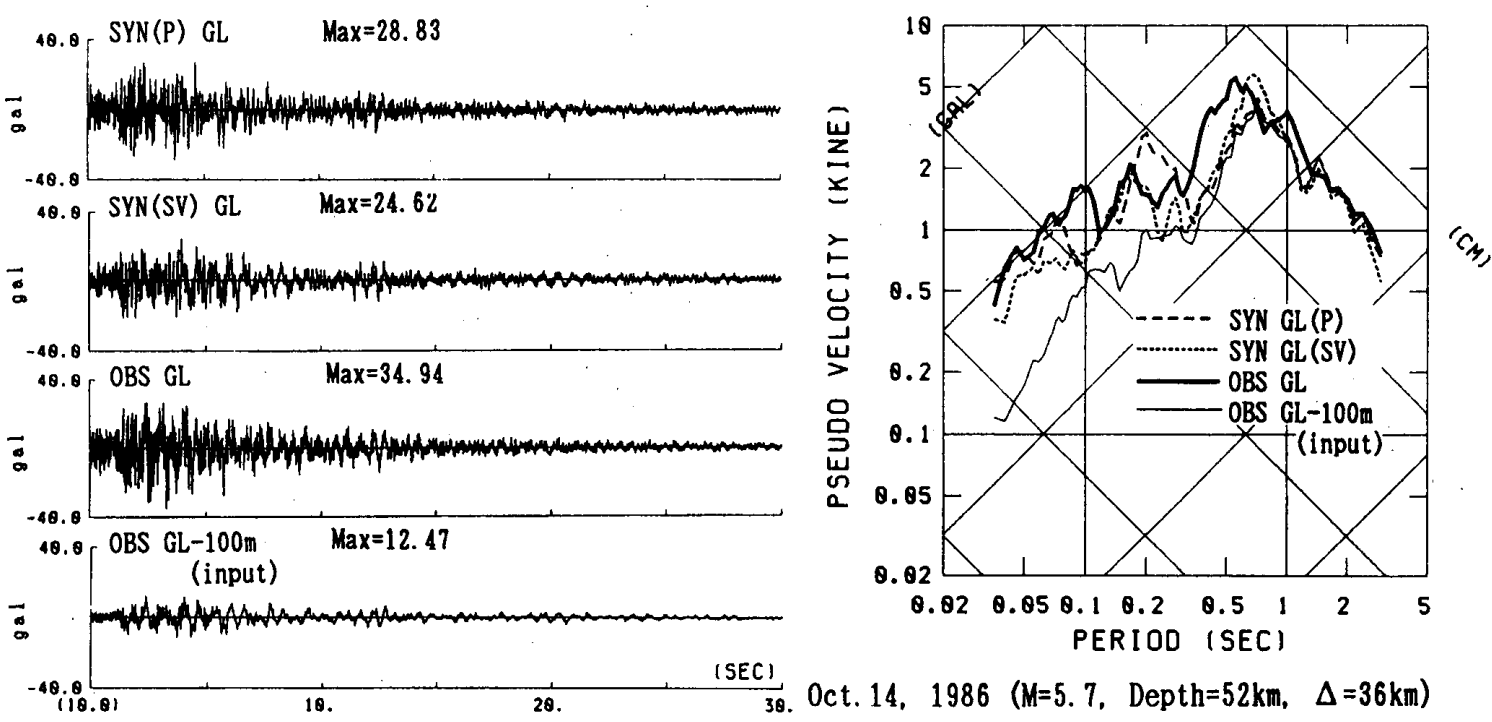

Fig.10 Comparisons of the vertical accelerograms synthesized by the multiple reflection theory due to $P$-wave or inclined SV-wave incidence and their response spectra with those of the observed record for $S$-wave part at TMK.
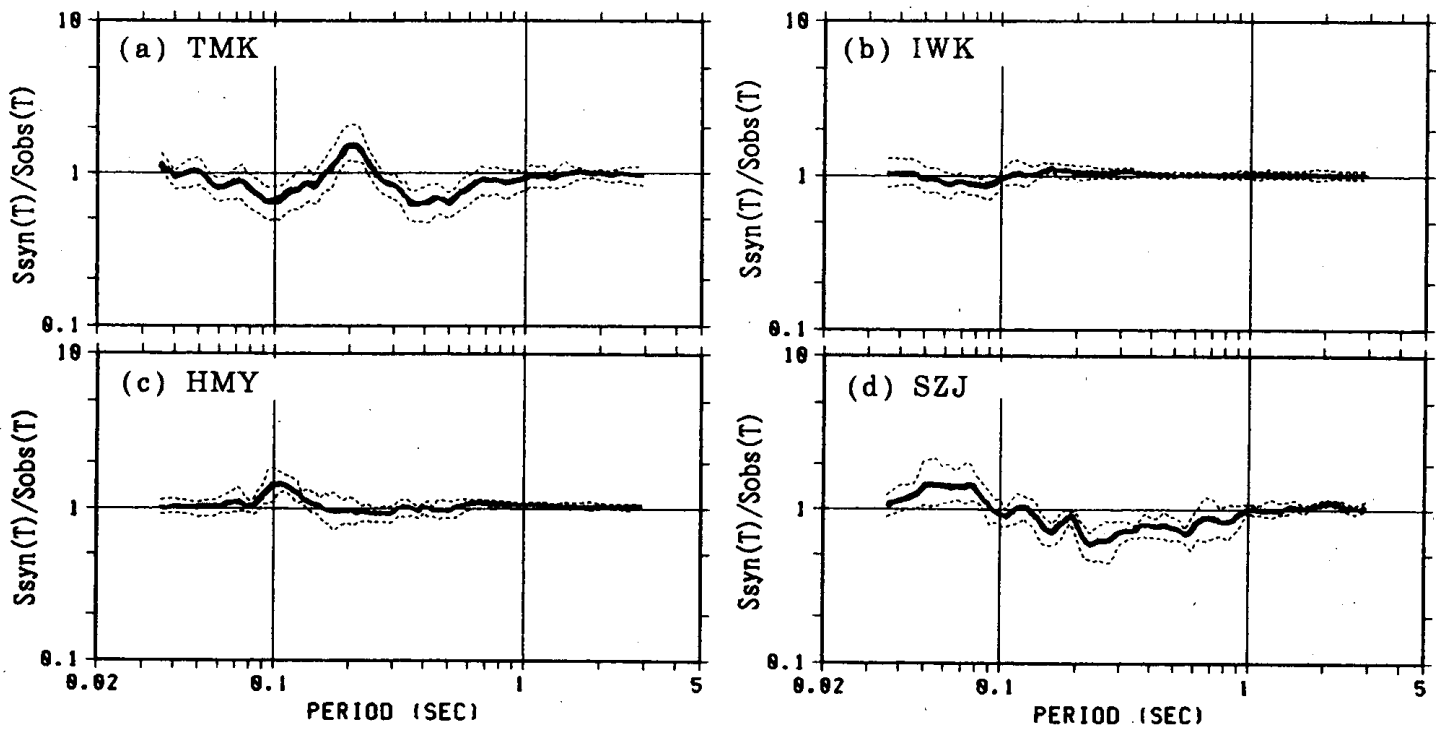

Fig.11 The ratios of response spectra of vertical accelerograms at the ground surface synthesized by the multiple reflection theory of $P$-wave to those of observed records for $\mathrm{S}$-wave part, which are shown by the drawings similar to Fig.9.

していることがわかる。このことは S 波部の上下動で は表層地盤の上層であたかも $\mathrm{P}$ 波が下層から鉛直入射 したような現象が起っていることを意味する。

4 観測地点における各上下動記録の $\mathrm{S}$ 波部について、 中間点以浅の地盤に $\mathrm{P}$ 波か鉛直入射すると仮定して求 めた地表の計算波形による応答スベクトルの観測值に 対する比の平均と標準偏差をFig.11に示す。シミュレ ーション結果はFig.9と比べほぼ同程度の精度であり、 ファクター1.5以内で地表の応答スペクトルが推定さ れていることが分かる。

\section{6. まとめ}

地表近くの第四紀層と深層の第三紀層から構成され る 4 観測地点の鉛直アレー観測記録を用いて、上下地 震動の堆積地盤内における波動伝播特性を検討した。 主な結果を以下にまとめる。

1） $\mathrm{P}$ 波初動に続く $\mathrm{P}$ 波部では基盤に入射した $\mathrm{P}$ 波が 表層地盤で多重反射する様子がTMKで確認できる。 また他の地点も含め最深点と地表とのスペクトル比 はP波の多重反射によってよく説明できる。

2） $\mathrm{S}$ 波初動に続く $\mathrm{S}$ 波部では、基盤に入射した $\mathrm{S} \mathrm{V}$ 波が基盤と表層との境界で $\mathrm{P}$ 波に変換し、その $\mathrm{P}$ 波 が多重反射する様子がTMKの上下動成分で確認でき 
る。このため基盤と地表とのスペクトル比は $\mathrm{S}$ 波部 といえども $\mathrm{P}$ 波部のそれによく似ており、 $\mathrm{S}$ 波部の 水平動を用いて求められたスペクトル比とは異なっ ている。

3） $\mathrm{P}$ 波部の上下動観測スペクトル比から最適化によ ってQp值を求めると、一部の例外を除き、表層地 盤の下層にあたる第三紀層では、 $\mathrm{Qp}(\mathrm{f})=\mathrm{Qpo} \cdot \mathrm{f}^{\mathrm{n}}$ と $\mathrm{Qp}(\mathrm{f})=\mathrm{Qs}(\mathrm{f}) \cdot(\mathrm{Vs} / \mathrm{Vp})^{\mathrm{n}}(\mathrm{n}=0.3 \sim 1.0)$ の関 係がほぼ成り立つ。この関係は $Q p$ と $\mathrm{Q}$ の周波数依 存性がほぼ同じであることおよび同一波長に対して 考えると Qp 值とQ $\mathrm{s}$ 值の絶対值がほぼ同じになるこ とを示している。このような性質は基盤層以深の伝 播経路で求められているQpとQsの関係とほぼ同じ である。これに対し表層地盤の上層にあたる第四紀 層では $\mathrm{Qp}(\mathrm{f})=\mathrm{Qpo} \cdot \mathrm{f}^{\mathrm{n}}$ の関係は同様に成り立つが、 同一波長に对する $\mathrm{Qp}$ の值は $\mathrm{Qs}$ 值よりやや小さくな る。限られた地点の結果でありこれらの性質が多く の地点に成り立つかどうか断定はできないが、 $\mathrm{P}$ 波 の影響が大きい上下動の性質を考える上で興味ある 結果である。

4）最適化による地盤構造を用いて、S 波部の上下動 の予測精度を考えるために中間点の観測記録を用い て地表の観測記録をシミュレーションした。1つは 中間点以浅に $\mathrm{P}$ 波の鉛直入射を仮定した多重反射理 論を適用したもの：他の 1 つは基盤層に S V 波が斜 め入射したとの仮定のもとに多重反射理論を適用し たものである。TMKの記録に対する結果から、両者 がほぼ同程度に地表の観測記録をシミュレーション できることが分った。さらに前者の方法による 4 観 測地点における多数の地表の記録のシミュレーショ ンを行った結果は観測記録の応答スペクトルを平均 值でファクター1.5以内に推定しえており、この予 測精度は $\mathrm{P}$ 波部に対し基盤から $\mathrm{P}$. 波の鉛直入射を仮 定して求めた結果とほぼ同程度である。このことは、 表層地盤の上層では上下動に対しP波があたかも鉛 直入射したような現象が起っていることを意味し、 2)の結論と整合する。

\section{謝辞}

本論文の原稿を丁寧に查読していただいた 2 人の審 查員に深く感謝いたします。なお、本研究は電力共通 研究による成果に基づくものである。関係各位に感謝 いたします。

\section{参考文献}

1) 例元ば、Watabe, M., M. Tohdo, O. Chiba and R. Fukuzawa ; Peak accelerations and response spectra of vertical strong-ground motions from near-field records in USA, 8th Japan Earthquake Engineering Symposium. pp. 301-306, 1990

2）丹羽正徳、芳賀勇治、横田治彦、田村保、阿世賀宏、藤堂 正喜、平澤光春 ; 東京湾岸部における動的設計用入力 地震動の検討、シンボジウム/ウォーターフロントにおけ る地祳動特性と地盤に関わる諸問題、日本建築学会関東 支部構造部会、pp. 51-56、1991.9

3）武村雅之、太田外気晴、稗團成人；地震動の平均応答スペ クトルを評価する释験式の物理的基礎、日本建築学会 椣造系論文報告集、第375号、pp. 1-9、1987.

4）藤堂正喜、羽鳥敏明、高棉克也、渡辺孝英、色摩康弘; 硬質地盤における応答スペクトルの距離减袁式、その 2 上下動、日本建築学会大会学術講演梗概集、pp. 365-366、 1994

5）武村雅之、池浦友則、高橋克也、石田寛、大島豊；堆積 地盤における地震波隇衰特性と地震動評価、日本建築学会 構造系論文報告集、第446号、pp. 1-11、1993

6）例えば、飯塚節夫、太田外気晴、足立憲彦、高橋克也、 広野進、石田寛、戸井田克 ; 富岡 1,000 m地震観惻孔におけ る検層結果、物理探查、第39巻、第2号、pp. 79-94、1986

7）藤堂正喜、羽鳥敏明、千葉修、高檽克也、西村功；アレー 地震観測記録にもとつく上下地震動特性の検討、その 4 地表付近の上下動に影響が大きいS P 変換波の特定、日本 建築学会大会学術講演便概集、pp. 81-82、1993

8）横田治彦; 東京の軟弱地盎における地中地震観測、 第5回地盤震動シンポシウム、pp. 39-44、1977

9）石田勝彦，小堤治；㓮性・减衰にゆらぎをもつ物理系に おける平均化に関する一考察、日本建築学会大会学術講演 梗概集、pp. 723-724、1988

10）横田治彦; 軟弱な表層地盤の振動性状（水平動および 上下動の伝達特性）、日本建築学会大会学術講演便概集、 pp. 605-606、1977

11）太田裕；地震工学への最適化法の適用、八户港湾SMAC 設置点の地下構造推定、日本建築学会論文報告集、 第229号、pp. 35-42、1976

12）佐藤春夫；ランタムムな不均質による地震波の散乱、地震、 Vol. 44、pp. 85-97、1991

13) Yoshimoto, K., H. Sato, S. Kinoshita and M. Ohtake ; High-frequency site effect of hard rocks at Ashio, Central Japan, J. Phys. Earth, Vol.41, pp. 327-335, 1993

14）例えば，阿部康彦、小林喜久治、天池文男; 地盤の $\mathrm{P}$ 波 减衰モテルに関する検討、日本建築学会大会学術講演 便概集、Pp. 141-142、1993

（1994年11月 8 日原稿受理，1995年 5 月 22 日採用決定） 